\title{
Quantifying bed roughness beneath contemporary and palaeo-ice streams
}

\author{
FRANCESCA A.M. FALCINI, ${ }^{1}$ DAVID M. RIPPIN, ${ }^{1}$ MAARTEN KRABBENDAM, ${ }^{2}$ \\ KATHERINE A. SELBY ${ }^{1}$
}

\author{
${ }^{1}$ Environment Department, Wentworth Way, University of York, Heslington, York, YO10 5NG, UK \\ ${ }^{2}$ British Geological Survey, The Lyell Centre, Research Avenue South, Edinburgh, EH14 4AP, UK \\ Correspondence: Francesca A.M. Falcini <famf500@york.ac.uk>
}

\begin{abstract}
Bed roughness is an important control on ice-stream location and dynamics. The majority of previous bed roughness studies have been based on data derived from radio-echo sounding (RES) transects across Antarctica and Greenland. However, the wide spacing of RES transects means that the links between roughness and flow are poorly constrained. Here, we use Digital Terrain Model/bathymetry data from a well-preserved palaeo-ice stream to investigate basal controls on the behaviour of contemporary ice streams. Artificial transects were set up across the Minch Palaeo-Ice Stream (NW Scotland) to mimic RES flight lines over Institute and Möller Ice Streams (Antarctica). We then explored how different data-resolution, transect orientation and spacing, and different methods, impact roughness measurements. Our results show that fast palaeo-ice flow can occur over a rough, hard bed, not just a smooth, soft bed, as previous work has suggested. Smooth areas of the bed occur over both bedrock and sediment covered regions. Similar trends in bed roughness values were found using Fast Fourier Transform analysis and standard deviation methods. Smoothing of bed roughness results can hide important details. We propose that the typical spacing of RES transects is too wide to capture different landform assemblages and that transect orientation influences bed roughness measurements in both contemporary and palaeo-ice-stream setting.
\end{abstract}

KEYWORDS: geomorphology, ice streams, radio-echo sounding, remote sensing

\section{INTRODUCTION}

This paper aims to measure the bed roughness of contemporary subglacial and deglaciated terrains at analogous length scales. We define bed roughness as the vertical variation of terrain over a given horizontal distance (Siegert and others, 2005; Rippin and others, 2011). Accurate quantification of bed roughness beneath ice sheets is important because it is a primary control on basal drag and therefore ice flow velocity (Siegert and others, 2005; Bingham and others, 2017). Subglacial obstacles of $\sim 0.5-1 \mathrm{~m}$ in both amplitude and horizontal wavelength have been shown theoretically to exert critical basal drag (Weertman, 1957; Kamb, 1970; Nye, 1970; Hubbard and Hubbard, 1998; Hubbard and others, 2000; Schoof, 2002); however, these obstacle dimensions lie below the resolution achievable by radio-echo sounding (RES) across ice sheets. Several authors have nevertheless explored the relationship of higher amplitude (several $100 \mathrm{~m}$ ) and longer wavelength (hundreds of $m$ to several $\mathrm{km}$ ) bed roughness and ice dynamics across ice sheets using available RES data. These analyses have suggested that beds beneath contemporary ice streams are relatively smooth, with roughness values decreasing downstream, whilst in surrounding areas of slower ice flow, the beds are relatively rougher (Siegert and others, 2004; Rippin and others, 2006, 2011; Callens and others, 2014). As a consequence, basal roughness is regarded as one of the controls on ice-stream location, in particular for ice streams not topographically controlled by deep valleys (Siegert and others, 2004; Bingham and Siegert, 2009; Winsborrow and others, 2010; Rippin, 2013).
While a relationship between bed roughness and ice dynamics is intuitive, quantifying such a relationship has proved elusive and several studies have produced findings that should be explored further. For example, it has been observed that fast flowing ice can also occur over a rough, hard bed (Schroeder and others, 2014). The reasons for a smooth bed underneath fast-flowing ice can be varied, for example the existence of fine-grained sediments vs. streamlined topography (Li and others, 2010; Rippin and others, 2014). Ice-stream beds can be smooth along ice flow (parallel) and rough across flow (orthogonal) (King and others, 2009; Bingham and others, 2017), showing that the direction of bed roughness measurements is extremely important. Palaeo-ice-stream beds show the same pattern (Gudlaugsson and others, 2013; Lindbäck and Pettersson, 2015). Geology can have a strong control on the roughness underneath fast-flowing ice as shown in previously glaciated gneiss terrains (Krabbendam and Bradwell, 2014). An increase in landform elongation ratios in a palaeo-ice stream has been related to the change from a rough to smooth bed (Bradwell and Stoker, 2015). The points raised by these studies demonstrate that bed roughness and its relationship to ice dynamics is complex. By using Digital Terrain Models (DTMs) from now-exposed palaeo-ice streams to calculate bed roughness, we propose that it may be possible to explore these complexities in more detail because the bed of a palaeo-ice stream can be directly observed over its entirety at much higher spatial resolutions than contemporary ice-stream beds. 
The bed roughness of contemporary ice sheets has been calculated along 1-D topographic profiles (from RES tracks) predominantly using two different approaches, frequency domain methods for example Fast Fourier Transform (FFT) analysis (e.g. Taylor and others, 2004; Siegert and others, 2005; Bingham and Siegert, 2007; Li and others, 2010; Rippin, 2013) and space domain methods for example Standard Deviation (SD) (Layberry and Bamber, 2001; Rippin and others, 2014). Radar specularity has also been used to infer bed roughness (e.g. Schroeder and others, 2014). The scale of bed roughness measurements has mostly been controlled by the spacing between flight tracks, and the along-track resolution, which is a function of the radar system used. Ice-sheet scale studies have typically used track spacing of several kilometres with an along track resolution of a few metres (Siegert and others, 2004; Rippin and others, 2006; Bingham and others, 2007). Higher resolution radar imaging by King and others $(2009,2016)$ and Bingham and others (2017) has shown topographic detail that cannot be captured by the larger scale studies, and is similar to the detail available on deglaciated terrains from DTMs and bathymetric data unconstrained by ice cover (e.g. Perkins and Brennand, 2014; Bradwell and Stoker, 2015; Margold and others, 2015). Using DTMs also allows bed roughness to be measured in 2-D and at much smaller scales. The resolution of DTMs is becoming finer, with pixels down to a few metres or less (e.g. LiDAR; Salcher and others, 2010; Putkinen and others, 2017). Analysis of DTMs from deglaciated areas provides an opportunity to show what is being missed when bed roughness measurements are interpolated across widely spaced RES transects. Bed roughness calculations made on this terrain can also be much more easily linked to the geomorphological and geological character of the bed because individual landforms and geological variation can be observed directly.

In this study, we compare the bed roughness of the deglaciated, Devensian, Minch Palaeo-Ice Stream (MPIS) and surrounding areas in NW Scotland, with the contemporary Institute and Möller Ice Streams (IMIS) in West Antarctica. The bed roughness of both ice streams is quantified along transects with the same grid spacing, but for the palaeo-ice stream is also calculated between transects. We test how several parameters influence the measurement and interpretation of bed roughness. Firstly, we gauge whether the method used to measure bed roughness, FFT analysis or SD, produces different results. Secondly, we explore whether RES track spacing is sufficient to capture bed roughness trends. Thirdly, we compare bed-roughness results from transects that have the same grid spacing as RES data with results calculated down to the DTM pixel resolution. Finally, we show how the orientation of transects in relation to ice flow direction influences bed-roughness results.

\section{DATA AND METHODS}

\subsection{Study sites and data}

The MPIS drained the NW sector of the British and Irish Ice Sheet during the Devensian (Weichselian) Glacial Period (116-11.5 ka BP) and has a well-documented glacial landform and sediment record (Bradwell and others, 2008a; Bradwell and Stoker, 2015; Fig. 1). Its onset zone lies in the mountainous NW Highlands of mainland Scotland, with peaks up to $\sim 1000 \mathrm{~m}$ above present-day sea level (m a.s.l.).
At its maximum extent, several ice-stream tributaries flowed from breaches (at $\sim 300 \mathrm{~m}$ a.s.I.) in the present-day watershed in the NW Highlands mainland out to the shelf edge, at $\sim 200 \mathrm{~m}$ below present-day sea level (Bradwell and others, 2007, 2016; Bradwell and Stoker, 2015; Krabbendam and others, 2016). MPIS likely reached its maximum extent at 26-28 ka (Chiverrell and Thomas, 2010; Clark and others, 2012; Praeg and others, 2015; Bradwell and others, 2016).

IMIS drain the West Antarctic Ice Sheet into Ronne Ice Shelf (Fig. 1). Ice surface velocities are up to $400 \mathrm{~m} \mathrm{a}^{-1}$ (Rignot and others, 2011). The inferred occurrence of sediments at the bed of Institute Ice Stream has been interpreted to be associated with a smooth bed (Bingham and Siegert, 2007; Siegert and others, 2016). The Ellsworth Trough Tributary, a tributary of Institute Ice Stream, is topographically controlled (Ross and others, 2012).

We compare MPIS with IMIS due to their relatively comparable scale. IMIS ice thickness varies between 50 and $3000 \mathrm{~m}$ (Fretwell and others, 2013). A maximum ice thickness of $750-1000 \mathrm{~m}$ has been modelled for MPIS (Hubbard and others, 2009; Kuchar and others, 2012). IMIS drain an area of $140000 \mathrm{~km}^{2}$ and $66000 \mathrm{~km}^{2}$, respectively (Bingham and Siegert, 2009), While MPIS drained an area of 15000-20000 km² (Bradwell and others, 2007; Bradwell and Stoker, 2015). Institute Ice Stream is up to $82 \mathrm{~km}$ wide and the fast flowing section of the main trunk is $100 \mathrm{~km}$ long (Scambos and others, 2004). MPIS was $40-50 \mathrm{~km}$ wide and $200 \mathrm{~km}$ long in total (Bradwell and Stoker, 2015). MPIS had a discharge flux of $12-20 \mathrm{Gt} \mathrm{a}^{-1}$ (Bradwell and Stoker, 2015) compared with 21.6 and 6.4 Gt a ${ }^{-1}$ for IMIS, respectively (Joughin and Bamber, 2005).

For contemporary ice streams in Antarctica, the data used were RES transects with an along track resolution of $10 \mathrm{~m}$, and a grid spacing of $30 \times 10 \mathrm{~km}$ (Rippin and others, 2014). Data were acquired in the 2010/11 austral summer using the Polarimetric Airborne Survey Instrument (PASIN) with a frequency of $150 \mathrm{MHz}$ (Ross and others, 2012). PASIN has retrieved bed-echoes through $4200 \mathrm{~m}$ thick ice (Vaughan and others, 2006). Crossover analysis gave RMS differences of $18.29 \mathrm{~m}$ for ice thickness (Ross and others, 2012). The location of the data was determined using a differential GPS with a horizontal accuracy of $\sim 5 \mathrm{~cm}$. The reflections returned from the ice-stream bed were processed semi-automatically. The ice thickness (calculated every $\sim 10 \mathrm{~m}$ ) was subtracted from ice surface elevations to calculate the bed elevations (Ross and others, 2014). For more detail on acquisition and processing of the RES data see Rippin and others (2014) and Ross and others (2012, 2014). This dataset was used by Rippin and others (2014) to calculate bed roughness using both FFT analysis and SD.

Two high-resolution datasets were used to calculate bed roughness of the MPIS. For the onshore area, the NEXTMap DTM with a $5 \mathrm{~m}$ horizontal resolution and a $1 \mathrm{~m}$ vertical resolution, was used (Bradwell, 2013). NEXTMap DTM tiles were downloaded from the Centre for Environmental Data Analysis (CEDA) Archive (Intermap Technologies, 2009). For the offshore area, Bathymetric Multi-Beam Echosounder Survey data (MBES) were used. The MBES data subset has a resolution of $4 \mathrm{~m}$ and encompasses the Little Minch and the southern area of The Minch (Fig. 1). The surveys around NW Scotland were undertaken by the Maritime \& Coastguard Agency (MCA) between 2006 and 2012. For more detail on acquisition and processing of MBES data see Bradwell and Stoker (2015) or the Reports 

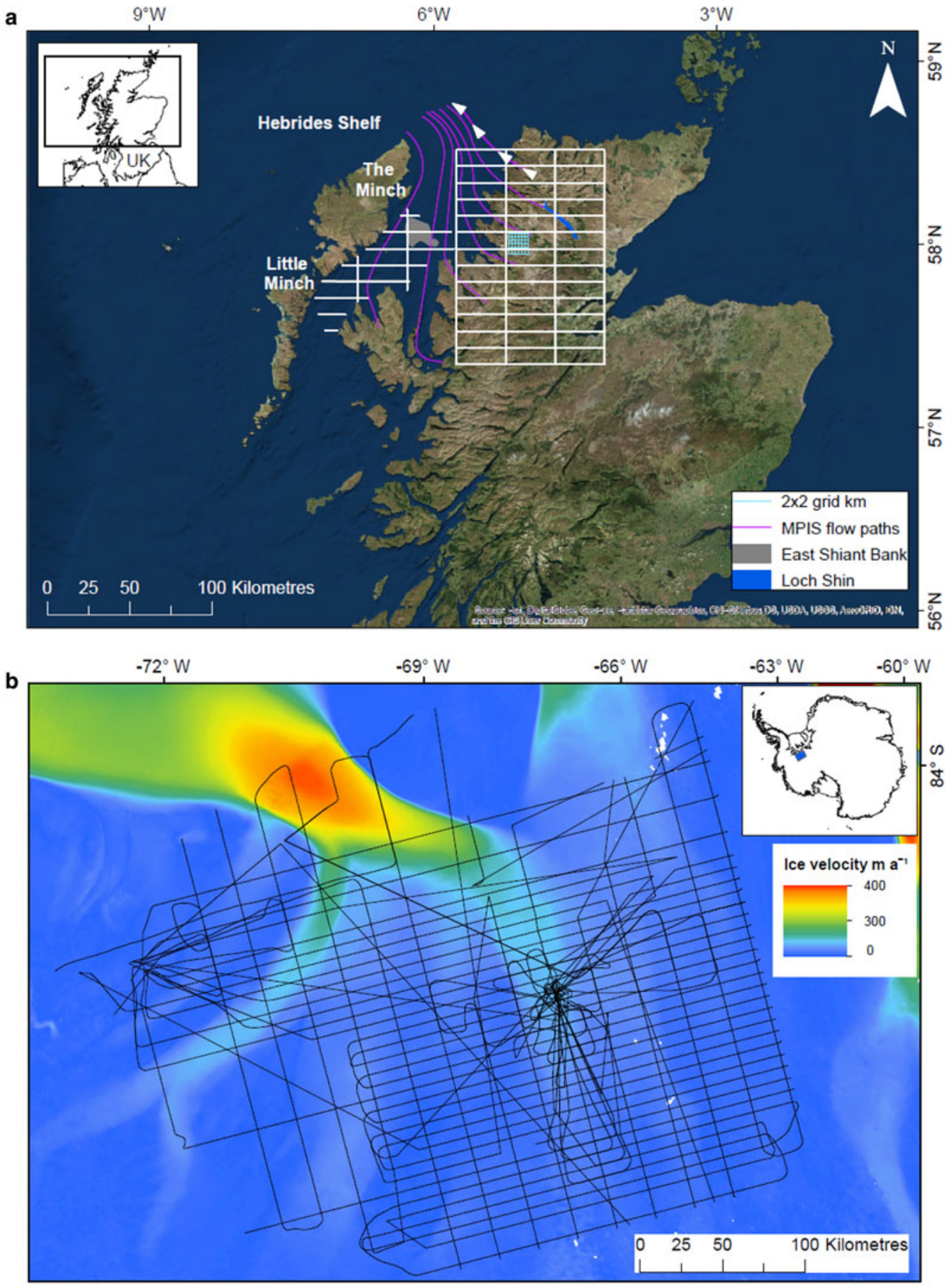

Fig. 1. Study site locations. (a) The Minch Palaeo-Ice Stream (MPIS), in NW Scotland. MPIS flow paths, that is areas of fast-flowing ice, are from Bradwell and others, (2007). The flow path with white arrows is the Laxfjord tributary. The coarse grid $(30 \times 10 \mathrm{~km})$ set up to mimic RES transects in (b), is shown in white. The fine grid $(2 \times 2 \mathrm{~km})$ is over the Ullapool megagroove area and is shown in cyan. Inset map shows the location of the main image. (b) Institute and Möller Ice Streams (IMIS), in West Antarctica. RES transects are shown in black. The inset map shows the location of IMIS (blue box). Ice velocity from Rignot and others (2011) and Mouginot and others, (2012).

of Survey, which can be requested from MCA, the UK Hydrographic Office, the British Geological Survey or the Natural Environment Research Council. MPIS is characterised by numerous elongate landforms that show a higher elongation ratio than those in adjacent areas (Bradwell and others, 2008b). Onshore, the bed of the palaeo-ice stream is dominated by bedrock (i.e. hard-bed) landforms (Krabbendam and Bradwell, 2010; Clark and others, 2018) including bedrock megagrooves, crag and tails, whalebacks and roches moutonnées (partly within a cnoc-and-lochan landscape, especially characteristic of Scotland's northwest region, Assynt), with few soft-sediment covered landforms (e.g. Bradwell and others, 2007; Bradwell, and others, 2008b; Krabbendam and Bradwell, 2011; Bradwell, 2013). In the Minch and further offshore on the Hebrides Shelf, the bed of the palaeo-ice stream comprises more soft-sediment landforms, such as drumlinoid features, although streamlined bedrock, crag-and-tail features and megagrooves are also present, particularly in the inner Minch (Bradwell and Stoker, 2015, 2016; Ballantyne and Small, 2018). Overdeepened basins occur, in particular, close to the present-day coast, which is in part characterised by a 
fjord system (Bradwell and Stoker, 2016; Bradwell and others, 2016). Increases in ice velocity are inferred from changes to landform elongation ratios located on the central Minch inner shelf (East Shiant Bank), which Bradwell and Stoker (2015) suggested is caused by the bed substrate changing from rough bedrock to smooth sediment.

\subsection{Methods}

Bed roughness along RES tracks in the Antarctic ice sheet and Greenland ice sheet has predominantly been quantified using either FFT analysis (e.g. Bingham and Siegert, 2009; Rippin, 2013; Rippin and others, 2014), or SD of bed elevations (e.g. Layberry and Bamber, 2001; Rippin and others, 2014). FFT analysis transforms bed elevations into wavelength spectra (Gudlaugsson and others, 2013), producing a power spectrum (Bingham and Siegert, 2009), which is a measure of the intensity (power) of different wavelength obstacles along a transect. SD is a measure of variation in amplitude. Applied to elevation data, a higher SD implies a greater spread between the high and low elevations, and thus a rougher bed. Both methods were used on MPIS and IMIS datasets to provide a comparison.

Both roughness methods were applied to a 2-D dataset from a deglaciated terrain, MPIS, and were compared with a 1-D dataset from a glaciated terrain, IMIS. We constructed an 'artificial' grid of transects spaced $30 \times 10 \mathrm{~km}$ apart over the high-resolution NEXTMap DTM and MBES bathymetry of the deglaciated MPIS to mimic a gridded RES survey over the glaciated IMIS (Fig. 1). The transect spacing replicates the spacing and resolution of RES transects used by Rippin and others (2014) on IMIS. Points were constructed every $10 \mathrm{~m}$ along all transects, and the $x, y$ and $z$ coordinates were extracted from NEXTMap DTM and MBES bathymetry.

Before bed roughness can be calculated using SD or FFT analysis, the elevation data have to be detrended to remove large wavelengths caused by mountains and valleys, which would otherwise dominate roughness measurements (Shepard and others, 2001; Smith, 2014). We are interested in roughness obstacles at a smaller scale than this, that is those which affect drag. The elevation data for each transect were detrended in $\mathrm{R}$ using the difference function (where difference $=2$ ). This detrending method does not require a moving window, which removes one of many variables that affect the final bed-roughness results (Prescott, 2013; Smith, 2014). SD was then calculated along transects using a moving window size of $320 \mathrm{~m}$ (32 points) following previous studies (e.g. Taylor and others, 2004; Li and others, 2010). Where transects crossed lakes and coast, bed roughness values were removed to prevent bias towards smooth surfaces (Gudlaugsson and others, 2013) using the Ordnance Survey Meridian 2 lake regions shapefile (Ordnance Survey, 2017). FFT analysis requires continuous along-track data. For gaps of $>100 \mathrm{~m}$ long (10 points), the transects were 'cut' (Rippin and others, 2014). Note that, in the onshore DTM analysis, a lake functions like a data gap. FFT analysis was not calculated across these gaps. Following previous studies (e.g. Taylor and others, 2004; Bingham and Siegert, 2009; Rippin and others, 2014), FFT analysis was calculated along transects using a window of $2^{N}$ points, where $N=5$ giving a window length of $320 \mathrm{~m}$ (32 points). The total roughness parameter was then defined by calculating the integral of the power spectra for every window. Roughness at all scales up to the length of the window was integrated.
The bed-roughness calculations from both methods were then interpolated using the Topo to Raster tool in ArcMap, with a $1 \mathrm{~km}$ output cell size. The interpolated values were smoothed with a $10 \mathrm{~km}$ radius circle and a buffer of $2.5 \mathrm{~km}$ was applied either side of the transects. This allowed us to replicate the type of processed results that would be extracted from a RES survey. The same method as described above was applied to the RES transects for IMIS. The difference in bed roughness values was calculated for MPIS and IMIS at locations where transects crossed. Most SD results presented here are not normalised, but shown as absolute values in metres. However, when presented alongside the FFT results, the SD results were normalised, to enable a comparison. Following the post-processing stages of interpolation, buffering and smoothing, the data were normalised using a linear transformation. The results from both sites and both methods were re-scaled so that values range between 0 and 1 .

A grid of transects spaced $2 \times 2 \mathrm{~km}$ apart was also created for the Ullapool megagroove area (Fig. 1), a well-characterised part of the onset zone of MPIS (Bradwell and others, $2008 \mathrm{~b})$. This finer grid was used to measure roughness in between the gaps created when widely spaced RES grids are used underneath contemporary ice sheets. A $2 \times 2 \mathrm{~km}$ grid allowed interpolation between transects and was aligned approximately parallel and orthogonal to palaeoice flow. Roughness was calculated using the same method as the larger grid, but the interpolation resolution was 200 $\mathrm{m}$, and the values were smoothed using a $2 \mathrm{~km}$ radius circle. Roughness was also calculated for transects parallel and orthogonal to palaeo-ice flow, allowing differences in bed roughness between palaeo-ice flow directions to be calculated. Within the area of the $2 \times 2 \mathrm{~km}$ grid, Bradwell and others (2008b) identified a bedform continuum, which equates to an erosional transition. This transition was interpreted as a thermal boundary by Bradwell and others (2008b), and bed roughness values from the inferred areas of warm and cold bed conditions were extracted from the smoothed interpolation, to quantify differences in roughness between these areas.

Finally, bed roughness was calculated over the entire onshore study area of the MPIS using a 2-D approach. The 2-D approach uses SD to calculate bed roughness across surfaces, rather than along 1-D transects. The 2-D method allows the full coverage and resolution of the NEXTMap data to be analysed, so that bed roughness can be calculated for the gaps in between 1-D transects. For every pixel, a circular window with a $320 \mathrm{~m}$ diameter was used for detrending and calculating bed roughness to match the results from the 1-D approach. The NEXTMap DTM was detrended by subtracting a smoothed bed from the original terrain. SD was calculated from the detrended raster for each $320 \mathrm{~m}$ circular window. We present both unsmoothed and smoothed 2-D data, to enable comparison with the smoothed 1-D results. Unsmoothed 2-D data allow us to look at the roughness calculations in more detail, whereas smoothed data show broader trends. Bed roughness was also calculated using the same approach above (except with a smaller $100 \mathrm{~m}$ window size) for all north-south pixels and all east-west pixels to assess directionality.

\section{RESULTS}

The 1-D roughness results calculated using SD for IMIS (Fig. 2c) are, as expected, similar to those found by Rippin 

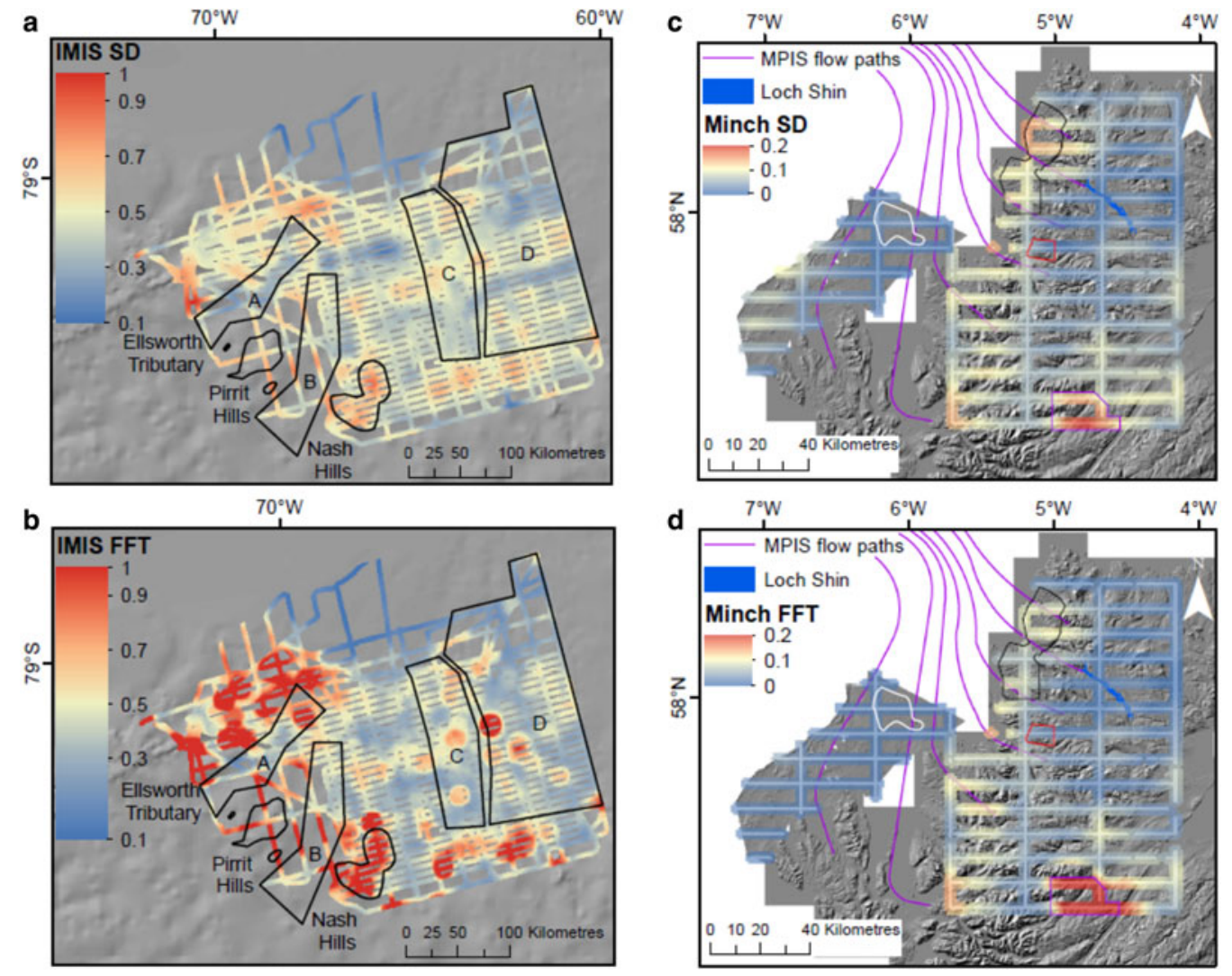

Fig. 2. Bed roughness calculated for MPIS and IMIS using SD and FFT analysis (window size $=320 \mathrm{~m}$ ). SD and FFT data are normalised. MPIS flow paths after Bradwell and others (2007). For MPIS; the Ullapool megagrooves are outlined in red, the cnoc-and-lochan landscape (including Assynt) to the north is outlined in black, the exposed bedrock (East Shiant Bank) in the Minch is outlined in white, and the Aird is outlined in purple. For IMIS, Institute Ice Stream tributaries are labelled A, B and C, whilst the Möller Ice Stream tributary is labelled D. (a) MPIS roughness derived from SD (m). (b) MPIS roughness derived from FFT analysis (total roughness parameter). (c) IMIS roughness derived from SD (m). (d) IMIS roughness derived from FFT analysis (total roughness parameter).

and others (2014) using FFT analysis (Fig. 2b). The locations of high and low values are similar but the relative magnitude of roughness trends appears reduced for SD (Fig. 2). Table 1 shows a slightly smaller range in roughness values for IMIS SD and similar means for both methods. It should be noted that SD roughness results are reported in the text as real values but are normalised in Figure 2 and Table 1 to enable comparison with FFT analysis. IMIS SD roughness values vary between $\sim 0.5$ and $4 \mathrm{~m}$. Lower roughness values of $0.5-1 \mathrm{~m}$ are generally located underneath the icestream tributaries, whereas higher roughness values (2.5$3.8 \mathrm{~m})$ are associated with the Pirrit Hills and Nash Hills in the intertributary areas. The Ellsworth Tributary, a tributary of Institute Ice Stream, has low bed roughness values except where it joins the main trunk $(\sim 2.7 \mathrm{~m})$. Similarly, Area D, a tributary of Möller Ice Stream, has mostly low

Table 1. Statistics of bed roughness results for MPIS and IMIS, using both methods

Site location and roughness Range Minimum Maximum Mean method

\begin{tabular}{lllll}
\hline MPIS SD & 0.25 & 0 & 0.25 & 0.08 \\
MPIS FFT analysis & 0.25 & 0 & 0.25 & 0.03 \\
IMIS SD & 0.9 & 0.1 & 1 & 0.46 \\
IMIS FFT analysis & 1 & 0 & 1 & 0.49
\end{tabular}

These are normalised values. The maximum value and minimum value across all datasets was used to normalize. roughness values, but with some higher bed roughness values (up to $2.8 \mathrm{~m}$ ). Areas B and C, tributaries of Institute Ice Stream, generally have rougher beds than Areas A and D (up to $3.4 \mathrm{~m}$ ). Parts of the inter-tributary area, however, have low roughness values $(1 \mathrm{~m})$. Thus, although there is a broad correlation between roughness and ice velocity, there are significant exceptions.

The SD bed roughness values for MPIS have a lower range (0-1 m) compared with IMIS (0.5-4 m). This also applies to the normalised SD values. The FFT bed roughness values for MPIS also have a lower range compared to IMIS (Table 1). The SD bed roughness values are lower $(0.1-0.5 \mathrm{~m})$ in the trunk of MPIS compared with the onset zones onshore (Fig. 2c). Most of the bed in the Minch is sediment covered, but some bedrock has been mapped (Fyfe and others, 1993; Bradwell and Stoker, 2015), which is slightly rougher $(0.2 \mathrm{~m})$ than the sediment dominated areas $(0.1 \mathrm{~m})$. The bedrock in the Minch is significantly smoother than the onshore bedrock of the cnoc-and-lochan landscape (Fig. 2c, d) in the onset zone (by up to $0.7 \mathrm{~m}$ ). The $30 \times 10 \mathrm{~km}$ grid is too low in resolution to give a detailed analysis of the transition between rough bedrock and smooth sediment in the Minch (Fig. 2). Within the Minch (bathymetry data), the flowlines coincide with smooth values $(\sim 0.1 \mathrm{~m})$ (Fig. 2). This pattern contrasts with most of the flowlines in MPIS onset zones (Fig. 2), where values are rougher $(0.2-0.9 \mathrm{~m})$. This compares to higher bed roughness values from IMIS, which vary from 1 to $2.9 \mathrm{~m}$ and $1-3.8 \mathrm{~m}$ in the tributary and intertributary areas, respectively (Fig. 2). The highest roughness values on 
the mainland of NW Scotland are found in the southern area (the Aird) of the $30 \times 10 \mathrm{~km}$ grid (1 m) (Fig. 2), whilst the lowest values are concentrated in the centre and east $(0.2 \mathrm{~m})$ (Fig. 2). The bed roughness results from SD and FFT analysis show similar trends in high and low values for MPIS (Fig. 2c, d). For example, over the Ullapool megagrooves, both methods produce bed roughness values of 0.1 (normalised values). However, the results calculated using SD are higher overall than those calculated from FFT analysis (higher mean in Table 1). This difference is largest over the cnoc-and-lochan area, where the SD results are up to 3.5 times higher. SD bed roughness results show slightly more variation than those calculated from FFT (Fig. 2C, d). For example, bed roughness values from the top east-west transect (Fig. 2c, d) are 0.01 when calculated using FFT analysis, but vary between 0.06 and 0.1 when calculated using SD.The bed roughness trends from the $30 \times 10 \mathrm{~km}$ grid (Fig. 3c) match those calculated from the smoothed 2-D approach (Fig. 3b) relatively well, particularly, the high roughness values over the cnoc-and-lochan landscape (3 m compared with $1 \mathrm{~m}$ ), and low roughness values over the central and NE areas. The unsmoothed 2-D results (Fig. 3a) give a much more detailed picture of bed roughness. Within the cnoc-and-lochan terrain there are significant local variations in roughness that are not apparent in the smoothed 2-D data (Fig. 3a, b), While the bedrock of the East Shiant Bank is visible in the unsmoothed roughness data but not the smoothed (Fig. 3a, b).

The $2 \times 2 \mathrm{~km}$ grid records higher roughness over the Ullapool megagrooves compared with the larger grid (0.3 m compared with $0.7 \mathrm{~m}$ ) (Figs 2 and 4 respectively). The distribution of bed roughness values between the areas interpreted by Bradwell and others (2008b) as cold and warm bed conditions (Fig. 4a) over the Ullapool megagrooves show a clear difference. The area with a cold bed has predominantly lower bed roughness values, with a mean of $0.2 \mathrm{~m}$, compared with the area where the bed was warm, with a mean of $0.4 \mathrm{~m}$ (Fig. 5). There is a clear transition to higher bed roughness values over the megagrooves compared with the surrounding areas (Fig. 4a).

\section{DISCUSSION}

Our results show that similar patterns of bed roughness are found in both contemporary and palaeo-ice stream settings, using the same transect spacing and along-transect resolution (Fig. 2). High and low roughness values can generally be found in areas of fast ice flow. This suggests that
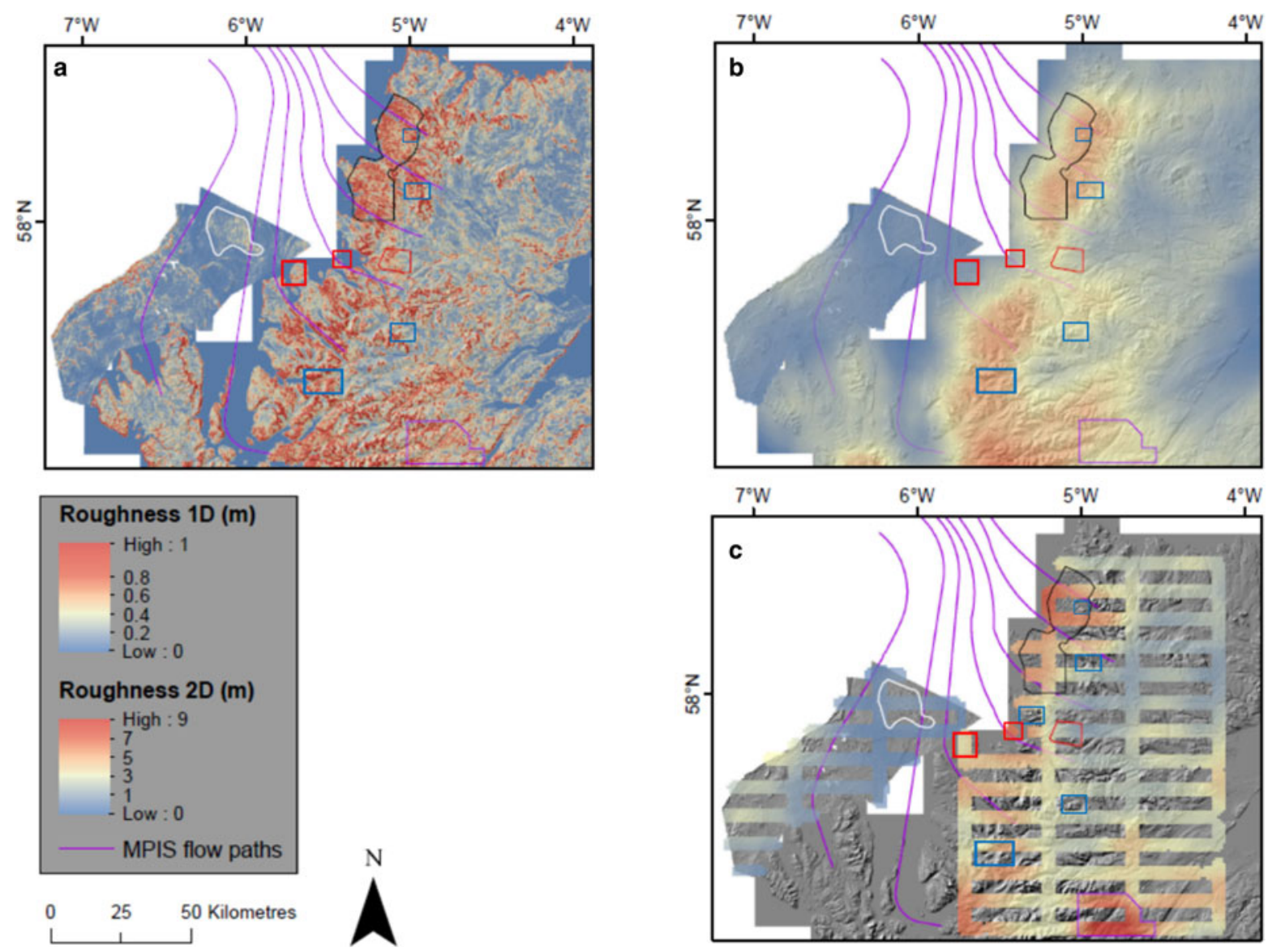

Fig. 3. Bed roughness calculated using SD for all NEXTMap DTM pixels using a moving window of $320 \mathrm{~m}$ (2-D). Values are not normalised. The exposed bedrock (East Shiant Bank) in the Minch is outlined in white. The Ullapool megagrooves are outlined in red. The cnoc-andlochan landscape (including the Assynt) to the north is outlined in black. The Aird is outlined in purple. (a) Bed roughness of MPIS onset zone with flow paths after Bradwell and others (2007). Blue boxes are inselbergs and mountain massifs that are missed by the 1-D 30 $x$ $10 \mathrm{~km}$ transects. These include Ben Mor Coigach massif, Ben Stack, the Assynt massif, the Fannichs, and Liathach. Red boxes show Loch Ewe and Little Loch Broom, which appear rough on the 1-D grid but smooth using the 2-D data. (b) Bed roughness from (a) that has been resampled to $1 \mathrm{~km}$ resolution and smoothed using the same window size as that used for the bed roughness measurements calculated using the $30 \times 10 \mathrm{~km}$ grid. (c) Bed roughness from the $1-\mathrm{D} 30 \times 10 \mathrm{~km}$. 
a
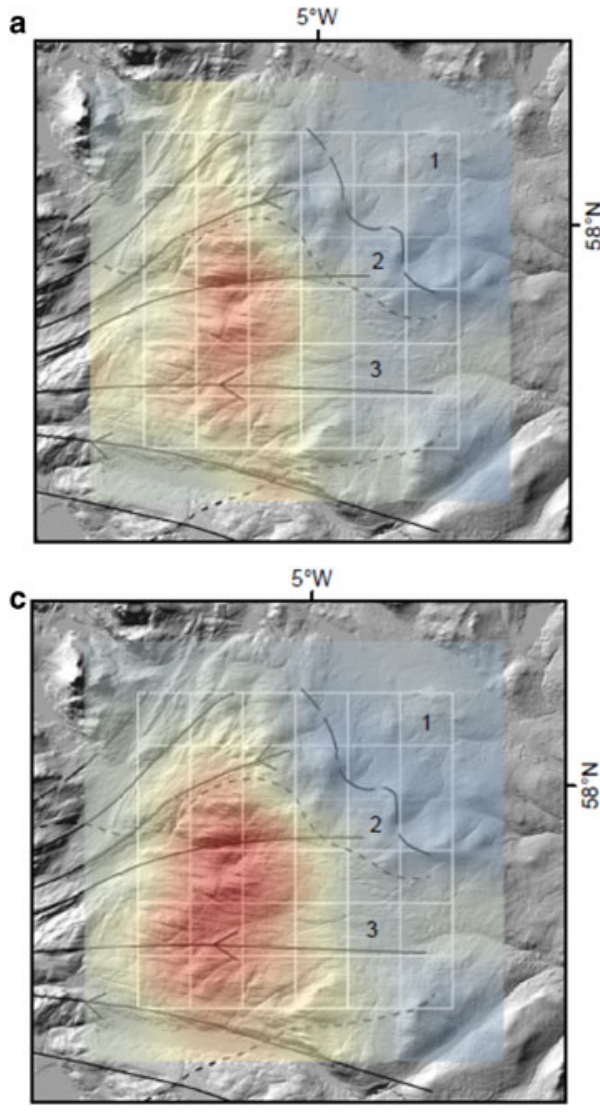

b

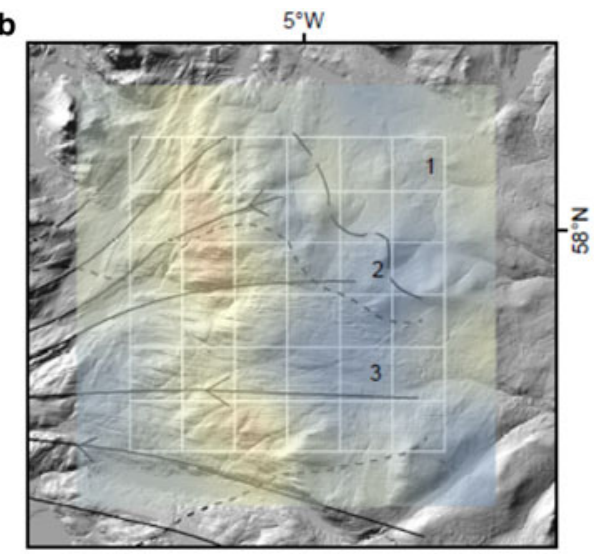

$5^{\circ} \mathrm{W}$

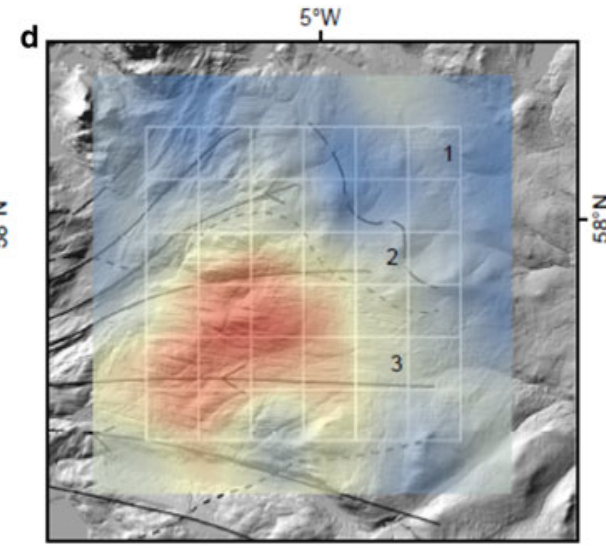

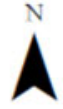

Roughness ( $\mathrm{m}$

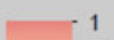

0.75

0.5

0.25

0

Difference $(\mathrm{m})$

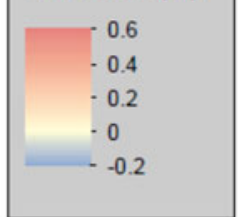

Fig. 4. Roughness measured along transects (white lines, grid spacing of $2 \times 2 \mathrm{~km}$ ) over the Ullapool megagrooves (see Fig. 1 for location). The transects are approximately parallel and orthogonal to palaeo-ice flow (Solid black lines with arrows, east to west). 1 is an area of no glacial streaming (cold-based ice), 2 is an area of subtle streamlined landforms between the dotted and dashed lines (warm-based ice). Between the dotted lines, 3 is an area of strong glacial streamlining (warm-based ice). Palaeo-flow direction and areas of glacial streaming after Bradwell and others (2008b). Values are not normalised. (a) Roughness calculated along all transects. (b) Roughness calculated along transects parallel to flow. (c) Roughness calculated along transects orthogonal to flow. (d) The magnitude difference between (b) and (c).

bed roughness is not always a controlling factor on the location of ice streaming. Overall, the bed roughness results for IMIS are higher than MPIS. One reason for this difference could be the vertical resolution of RES data, which is lower compared with DTM data (5 $\mathrm{m}$ vs. $1 \mathrm{~m}$, respectively). Postglacial sedimentation could be one of the causes of this. For example, a thin layer $(0.1-10 \mathrm{~m})$ of postglacial sediment deposition occurs in the Minch (Fyfe and others, 1993; Bradwell and Stoker, 2015), which will reduce the amplitude of small-scale glacial features. Yet this is unlikely to be the case onshore, where predominantly exposed bedrock with more localised areas of postglacial sediment prevails (Krabbendam and Bradwell, 2010). Conversely, topographic profiles collected using RES are an average of the radar trace (King and others, 2016), which could cause such data to be slightly smoothed in comparison with data from visible surfaces for example DTMs. Without being able to see the entire bed of IMIS it is difficult to provide a definitive answer. We suggest that the reason for higher bed roughness in IMIS could be due to the difference in elevation range
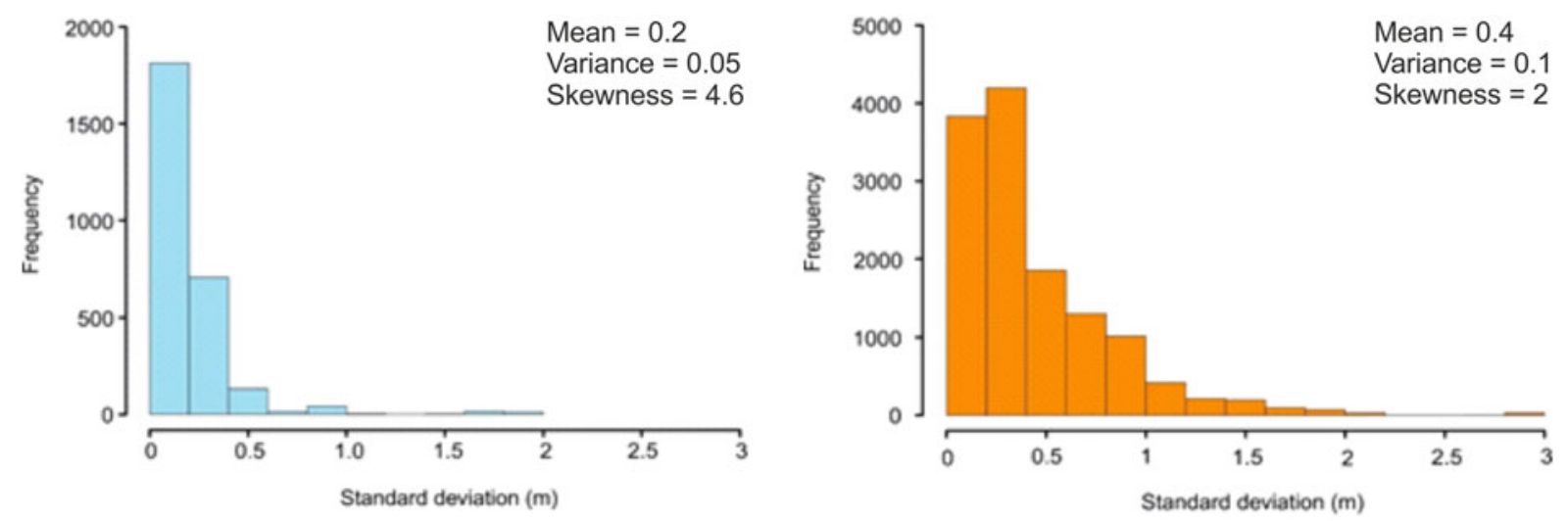

Fig. 5. Bed roughness distributions in cold-based (blue) and warm-based (orange) areas from the $2 \times 2 \mathrm{~km}$ grid over the Ullapool megagrooves. Cold-based and warm-based areas are defined by Bradwell and others (2008b). Values are not normalised. 
between the two locations. MPIS has an elevation range of $1493 \mathrm{~m}$, While IMIS has an elevation range of $3582 \mathrm{~m}$ (Fretwell and others, 2013).

\subsection{SD vs. FFT analysis methods}

Our comparison between SD and FFT analysis at the 1-D scale for MPIS and IMIS showed similar broad trends of bed roughness, but there were differences (Fig. 2). For MPIS, the cnoc-and-lochan landscape appears rougher in the SD than in FFT (Fig. 2). Cnoc-and-lochan landscapes typically contain abundant lakes, which appear on a DTM as a flat surface. These are removed from the dataset to avoid bias towards a smooth surface. For FFT analysis to be carried out, transects measuring $<320 \mathrm{~m}$ between lakes are also removed from the data, causing data gaps. Where there are multiple lakes along a transect with $<320 \mathrm{~m}$ between them, the SD method measures a high roughness value. FFT analysis cannot capture this variation in terrain. Some transects that are not impacted by lakes also have higher bed roughness values calculated from SD compared with FFT analysis. Both methods essentially measure the amplitude of the bed obstacles (Rippin and others, 2014), but FFT analysis measures the frequency of vertical undulations (Bingham and Siegert, 2009). We suggest that the FFT analysis is measuring similar frequencies of elevation change. The results from the SD method for the same landscape are rougher than FFT analysis, because it is measuring large amplitude changes between the numerous hills and lakes. Furthermore, FFT analysis (total roughness parameter) integrates roughness at all scales up to the window size, whereas SD is calculated for the window size only. This will cause higher roughness results measured using SD because the values are calculated over a larger horizontal length-scale (Shepard and others, 2001). Both methods have advantages and disadvantages in their application. FFT analysis emphasises roughness frequency whilst SD provides a more intuitive measure of roughness scales.

\subsection{Transect spacing vs. complete coverage: what is missed?}

Measuring bed roughness on a palaeo-ice stream allows us to assess the validity of RES transect spacing used to measure bed roughness on contemporary ice streams. The $30 \times 10 \mathrm{~km}$ grid misses key areas of glacial landforms used to interpret MPIS ice dynamics, such as the transition from rough bedrock to smooth sediments in the bathymetry data (Fig. 2) (Bradwell and Stoker, 2015). For the onshore data, shifting the $30 \times 10 \mathrm{~km}$ grid by a few $\mathrm{km}$ north or south would miss the Ullapool megagrooves altogether (Fig. 2). Entire inselbergs and mountain massifs are missed (blue boxes on Fig. 3): in the 2-D roughness maps these areas appear as very rough and it is known these had a profound effect on local ice dynamics (Bradwell, 2005, 2013; Finlayson and others, 2011). Conversely, some areas appear rough on the 1-D transect but appear on the 2-D maps as fairly smooth (red boxes on Fig. 3). A much more detailed picture of 2-D bed roughness trends can be achieved without the smoothing employed by previous studies (Fig. 3a) (e.g. Rippin and others, 2014). For example, all the cnocand-lochan area appears rough on the smoothed 2-D data, but the unsmoothed data show that some parts are smooth (Fig. 3a, b). The 2-D method surpasses the detail that can be captured by the 1-D transects but does not allow for analysis of the bed roughness directionality (anisotropy). It is clear that exploring palaeo-ice-stream roughness is possible at much higher resolutions than for contemporary ice streams, and important insights regarding the roughness of subglacial terrain may thus be learnt from these environments (Gudlaugsson and others, 2013).

A $30 \times 10 \mathrm{~km}$ grid is too widely spaced to capture bed roughness of some landform assemblages. The question of what grid size should be used is an important one. The Ullapool megagrooves for example, cover an area of $6 \times 10 \mathrm{~km}$ and individual grooves are up to $4 \mathrm{~km}$ long (Krabbendam and others, 2016). A grid size of $2 \times 2 \mathrm{~km}$ is arguably more suitable (Fig. 4). The size of glacial landforms that can be measured at DTM resolution varies largely, $\sim 10-10^{5} \mathrm{~m}$ (Clark, 1993; Bennett and Glasser, 2009) and a grid size that can measure mega-groove bed roughness might not be appropriate for other landform assemblages. The landscape underneath ice streams has been captured in detail using RES grids with transects spaced $500 \mathrm{~m}$ apart (King and others, 2009, 2016; Bingham and others, 2017). Importantly, these studies only used orthogonal transects because RES can pick up multiple landform crests parallel to ice flow (King and others, 2016). Acquiring RES tracks at $500 \mathrm{~m}$ spacing for large areas is very challenging, but future surveys could be focused on locations where rough, streamlined topography is thought to be present (Bingham and others, 2017), or areas that could cause a future sea level rise through rapid retreat for example Thwaites Glacier (Joughin and others, 2014; DeConto and Pollard, 2016). Drones or Unmanned Aerial Vehicles have the potential to make RES data collection with small track spacing more viable over large areas (e.g. Leuschen and others, 2014).

\subsection{The importance of transect orientation}

The locations of high roughness values over MPIS, measured by both SD and FFT analysis along transects, do not always reflect qualitative roughness seen in the DTM and bathymetry data. This problem has been investigated previously for bed roughness (e.g. Gudlaugsson and others, 2013; Rippin and others, 2014) and englacial layers (e.g. $\mathrm{Ng}$ and Conway, 2004; Bingham and others, 2015), and transect orientation was shown to be important. To explore the influence of transect orientation on bed roughness we calculated bed roughness separately for north-south and east-west transects for both MPIS and IMIS (Fig. 6). Where transects cross each other, the difference in roughness was calculated (Fig. 6c, f). This was also done for transects on a pixel scale spacing for MPIS (Fig. 7). The difference in roughness of cross-cutting transects can be seen as a measure of directionality (anisotropy).

In MPIS some areas show a difference between east-west and north-south transects, suggesting significant anisotropy. The north-south transect along the West coast has higher roughness values (Fig. 6), notably for the lower part of the cnoc-and-lochan landscape on the exposed gneiss bedrock in the Assynt area (Krabbendam and Bradwell, 2014) and the edge of Ullapool mega grooves area (Bradwell and others, 2008b). This same pattern is also apparent in more detail at the pixel scale (Fig. 7). In the Minch, the east-west pixels are rougher over the exposed bedrock (East Shiant Bank) (Fig. 7c), which is not shown in Figure 6 because of the wide transect spacing. In both cases, the rougher 

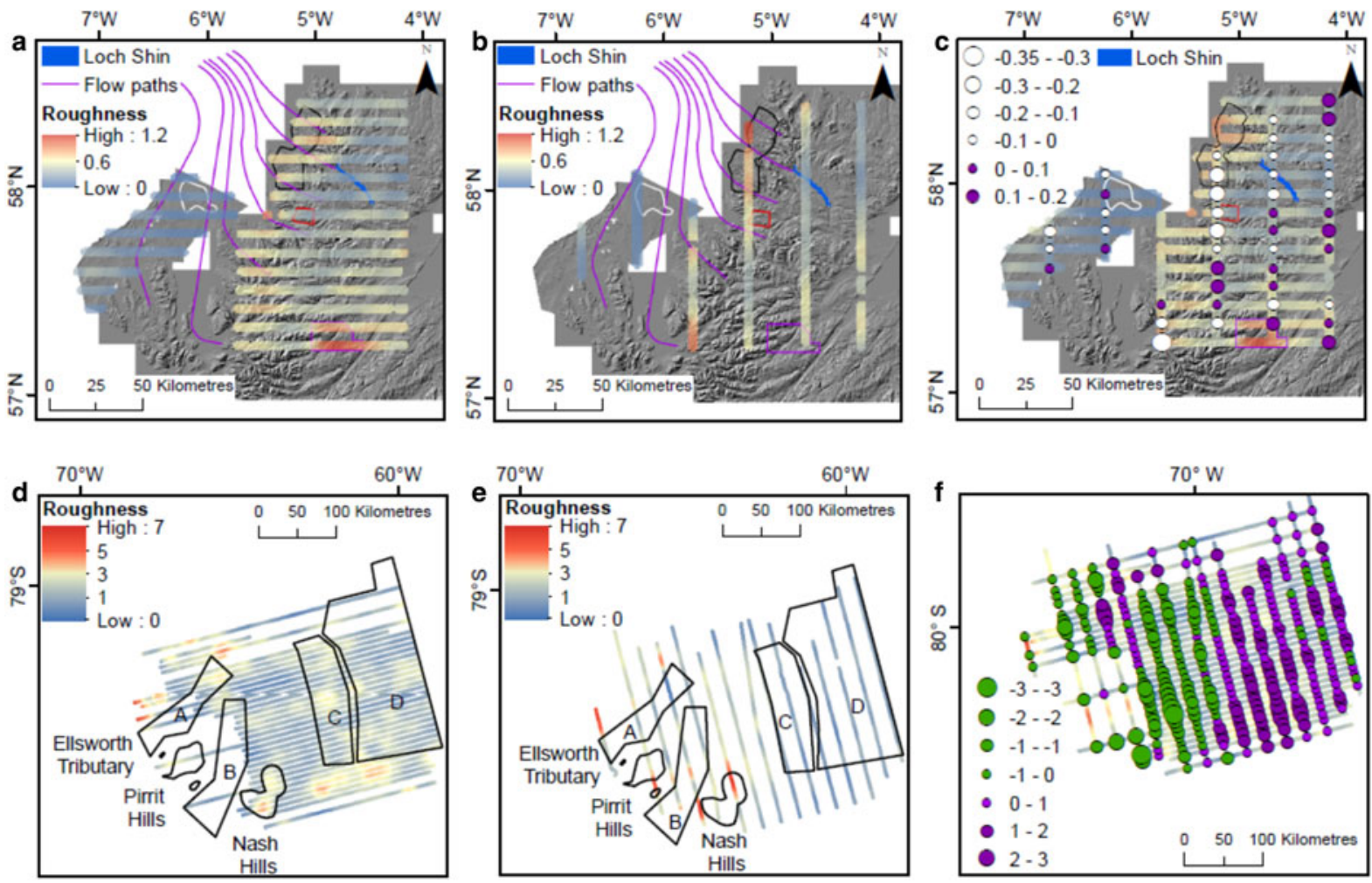

Fig. 6. The relationship between bed roughness measurements and transect orientation for MPIS and IMIS. All bed roughness measurements were calculated using SD and values are not normalised. For MPIS: The exposed bedrock (East Shiant Bank) in the Minch is outlined in white. The Ullapool megagrooves are outlined in red. The cnoc-and-lochan landscape (including the Assynt) to the north is outlined in black. The Aird is outlined in purple. (a) Bed roughness for east-west MPIS transects. (b) Bed roughness for north-south MPIS transects. (c) The proportional circles show the east-west transects minus the north-south for MPIS. (d) Bed roughness for east-west IMIS transects. (e) Bed roughness for north-south IMIS transects. (f) The proportional circles show the east-west transects minus the north-south transects for IMIS.

transects are orthogonal to palaeo-ice flow and support previous observations of bedrock smoothing by streaming ice (Bradwell and Stoker, 2015; Ballantyne and Small, 2018). The east-west transects crossing the Aird are rougher than the north-south transects (Fig. 6). Closer inspection of the NEXTMap DTM reveals these rough values are located where the east-west transects cross deeply incised river valleys. Post-glacial erosion or sediment deposition can impact on palaeo-ice-stream bed roughness values. In IMIS east-west transects have higher roughness values predominantly in the tributaries labelled C and D, whilst the north-south transects have higher roughness values under tributaries A and B (Fig. 6). Although the direction of these transects is not related to ice flow as analysed by Rippin and others, (2014), it shows that the direction of transects influences the bed roughness results for both contemporary and palaeo-ice streams.

For contemporary ice streams it has been shown that the transect orientation in relation to ice flow can bias interpretation (e.g. Rippin and others, 2014; Bingham and others, 2015; Bingham and others, 2017). Parallel to ice flow, the data tend to show smooth beds (Lindbäck and Pettersson, 2015) and undisrupted ice layering (Bingham and others, 2015), whereas data orthogonal to ice flow can show rough topography (Rippin and others, 2014; Bingham and others, 2017), which can be caused by streamlined features, for example mega grooves or mega-scale glacial lineations. These landforms have strong anisotropy (Spagnolo and others, 2017). The advantage of looking at palaeo-icestream beds compared with contemporary ice-stream beds is that the landforms can be observed directly. The strong anisotropy of the Ullapool megagrooves, already known from traditional geomorphological studies (Bradwell and others, 2007; Krabbendam and others, 2016), is well captured by the $2 \times 2 \mathrm{~km}$ grid results (Fig. 4b, c, d). Flow parallel transects are smoother $(0.4 \mathrm{~m})$, than the orthogonal transects $(1 \mathrm{~m})$. The roughness orthogonal to palaeo-ice flow is up to $2 \times$ higher than parallel palaeo-ice flow. The same pattern is shown in Figure 7. The formation of hard-bed megagrooves smooths the bed along ice flow but may lead to increased roughness orthogonal to ice flow, for instance by lateral plucking (Krabbendam and Bradwell, 2011; Krabbendam and others, 2016).

\subsection{Roughness as a control on ice-stream location}

The bed-roughness measurements extracted across MPIS using the 1-D and 2-D SD methods show that high roughness values occur in some areas interpreted as having hosted fast palaeo-ice flow (see MPIS flow paths, Figs 2 and 3). A rough bed underneath fast-flowing ice is not typically assumed and is at odds with some previous findings from contemporary ice streams that show low roughness values, i.e. a smooth bed, beneath fast-flowing ice (e.g. Siegert and others, 2004; Bingham and Siegert, 2007; Rippin and others, 2011). Warm basal ice will be present in fast flowing areas whilst ice underneath slow flowing regions is likely to be frozen at the bed (Benn and Evans, 2010). Bradwell and others (2008b) interpreted areas of cold and warm basal conditions for the Ullapool megagrooves and adjacent areas (Fig. 6). 

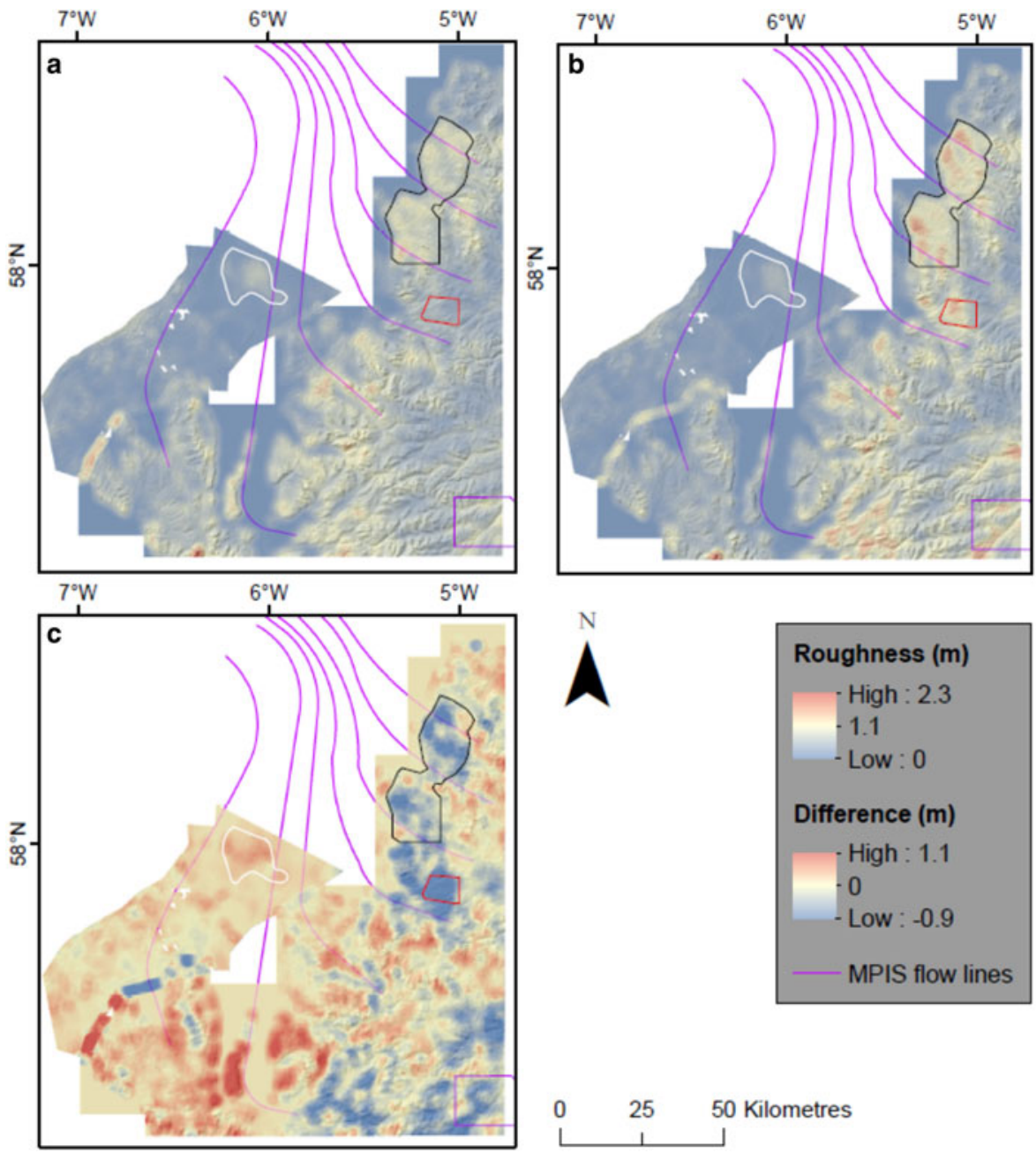

Fig. 7. The relationship between bed roughness measurements and transect direction for MPIS on a pixel scale. All bed roughness measurements were calculated using SD (window size $=100 \mathrm{~m}$ ) and values are not normalised. The same interpolation and smoothing done for Figure 4 was used here. The exposed bedrock (East Shiant Bank) in the Minch is outlined in white. The Ullapool megagrooves are outlined in red. The cnoc-and-lochan landscape (including Assynt) to the north is outlined in black. The Aird is outlined in purple. (a) Bed roughness values calculated for each row of the DTM (east-west). (b) Bed roughness values calculated for each column of the DTM (north-south). (c) Plot of east-west minus north-south bed roughness.

Bed roughness values are lower for the areas with cold basal conditions compared with the areas with warm basal conditions (Fig. 5). Bradwell and others (2008b) identified a marked change in the bedform continuum between coldbased and warm-based zones and suggested this was due to increased ice velocity. Thus, we suggest that areas of inferred slow palaeo-ice flow can be associated with a smooth bed. Higher erosion rates under the fast-flowing palaeo-ice have produced larger, elongated bedforms, which have left behind a rougher bed overall (particularly orthogonal to palaeo-ice flow). It must be noted that this is for an area of exposed bedrock, with no sediment cover.

Krabbendam (2016) argued that if there is a thick layer of temperate basal ice, fast flow can occur on a rough hard bed. In this setting, less basal drag occurs and thick temperate basal ice is maintained by frictional heating, which produces high basal melt rates. The Laxfjord Palaeo-Ice Stream is a tributary to MPIS, identified by Bradwell (2013) (Fig. 1). Erosional landforms such as whalebacks and roches moutonnées were mapped on the bed of the Laxfjord Palaeo-Ice Stream, in the cnoc-and-lochan landscape (Bradwell, 2013). These landforms are indicative of warm-based ice with meltwater present at the bed (Bennett and Glasser, 2009; Benn and Evans, 2010; Roberts and others, 2013). Bradwell (2013) suggested that topographic funnelling of ice was the driver of palaeo-fast ice flow in the Loch Laxford area. MPIS has a dendritic network of overdeepened valleys that channelled ice into the main trough and is thought to be topographically controlled (Bradwell and Stoker, 2015). It thus appears that rough beds are possible in topographically steered ice streams and that topographic steering may 'trump' roughness as a control on icestream location (see also Winsborrow and others, 2010).

Recent insights from contemporary ice streams support our results from MPIS. Schroeder and others (2014) demonstrated that the lower trunk of the fast-flowing Thwaites Glacier is underlain by rough bedrock. Jordan and others (2017) found that warm-based areas, predicted by MacGregor and others (2016), underneath the northern part of the Greenland ice sheet, are relatively rough compared with predicted cold-based areas. A tributary to Institute Ice Stream, Ellsworth Tributary (Fig. 2), is topographically controlled (Ross and others, 2012), and Siegert and others (2016) suggest that this explains why fast flow occurs over rough areas of the bed. The suggested reasons for a rough bed underneath the Ellsworth Tributary are an absence of 
sediment deposition or excavation of pre-existing sediment (Siegert and others, 2016). In MPIS in Scotland and surrounding areas, there is a strong geological control on roughness (Bradwell, 2013; Krabbendam and Bradwell, 2014; Krabbendam and others, 2016). This could be the underlying cause for the rough bed underneath the Ellsworth Tributary.

Our results suggest that the bed roughness of a palaeo-ice stream and a contemporary ice stream are comparable, and support the notion that palaeo-ice streams can be used as analogues for contemporary ice streams (Bradwell and others, 2007; Rinterknecht and others, 2014; Bradwell and Stoker, 2015).

\subsection{Interpreting sediment cover from roughness calculations}

Bed roughness values from IMIS were smoother underneath the ice-stream tributaries compared with the intertributary areas (Fig. 2). Smooth beds beneath ice streams are typically explained by the inferred presence of soft sediment (Siegert and others, 2005; Li and others, 2010; Rippin, 2013). However, the Ullapool megagrooves (exposed bedrock features, without sediment cover) (Bradwell and others, 2008b), are smooth, particularly parallel to palaeo-ice flow (Figs 4 and 7). Equally the East Shiant Bank includes bedrock but is barely rougher than the adjacent, sediment-covered parts of the MPIS (Fig. 2). Smooth areas of below present-day ice streams may therefore not necessarily be sediment covered.

\subsection{Recommendations for future studies}

The direction of transects influences the bed roughness results on palaeo- and contemporary ice streams. We suggest that future acquisition of RES tracks over contemporary ice streams are orientated parallel and orthogonal to flow where possible. The fine spacing of RES tracks that is $500 \mathrm{~m}$ orthogonal to ice flow only, could be focused on locations where the bed is thought to be rough underneath fast-flowing ice as this has been shown to have an impact on ice flow (Bingham and others, 2017). Further analysis of the relationship between grid size, bed roughness and landforms assemblages is needed on palaeo-ice streams to give recommendations on the appropriate grid sizes. For palaeo-ice streams, including MPIS, bed roughness could be explored parallel and orthogonal to inferred flow lines (e.g. Gudlaugsson and others, 2013) to increase our understanding of the relationship between bed roughness and ice flow direction. The bed roughness of palaeo-ice streams dominated by sediment landforms (soft bed), could be compared with contemporary ice streams that are thought to have similar bed properties. Palaeo-ice streams provide an opportunity to improve our understanding of the relationship between landforms and bed roughness, and in turn, ice dynamics. The difference in what the SD and FFT analysis methods are measuring should be taken into account when these methods are applied in future studies. The effect of post-glacial erosion or sediment deposition on palaeo-ice-stream bed roughness values should also be taken into consideration.

\section{CONCLUSION}

We compared the bed roughness of the deglaciated Minch Palaeo-Ice Stream in Scotland, to the contemporary Institute and Möller Ice Streams in West Antarctica, using two analysis methods. We also investigated whether different grid spacing and orientation impact bed roughness measurements. The $30 \times 10 \mathrm{~km}$ grid, which matches a previous RES transect distribution used for bed roughness studies over a large area on contemporary ice streams, is too coarse to confidently capture all the different landforms on a typical ice-sheet bed. Using a finer $2 \times 2 \mathrm{~km}$ grid we were able to show that transects parallel to palaeo-ice flow were smoother compared with orthogonal transects over the Ullapool megagrooves in the onset zone of MPIS. A clear difference in bed roughness values was also shown for pixel scale transects for MPIS, demonstrating how transect orientation influences roughness results. RES transects should be closer together in future studies and orientated in relation to ice flow where possible. This would allow for more representative bed roughness measurements because of the importance of flow direction on roughness patterns. SD produced similar results to FFT analysis for the majority of the data, but there were some differences which should be taken into account by future studies. Unsmoothed 2-D roughness data for MPIS showed detail that is missed when 2-D Data are smoothed.

Most MPIS flow paths in the onshore onset zones coincided with high bed roughness values, whilst lower roughness values were associated with sediment cover in the main ice stream trunk. Yet, smooth areas of the bed beneath MPIS occurred over bedrock as well as the sediment-covered areas. Low bed roughness beneath contemporary ice streams is not a reliable indicator of the presence of sediment. In this study, we found that fast palaeo-ice flow has occurred over areas with high bed roughness values. Previous research often assumed that fast-flowing ice streams are generally related to areas of low roughness. High and low bed roughness values were also found in the IMIS tributaries, which supports the notion that palaeo- and contemporary ice streams are comparable in terms of bed roughness. The diverse topography underneath ice streams needs to be measured in more detail to increase our understanding of what controls ice stream location. Palaeo-ice streams provide useful analogues for bed roughness underneath contemporary ice streams, and both can be used to inform the other.

\section{ACKNOWLEDGEMENTS}

This research is part of a PhD project, funded by NERC, grant number NE/K00987/1. MBES data are Crown copyright and provided by the British Geological Survey (BGS), and Maritime and Coastguard Agency. OS Meridian data are provided by the Ordnance Survey, Crown copyright and database right 2012. NEXTMap DTM was provided by NERC via the Centre for Environmental Data Analysis (CEDA). RES data came from UK NERC AFI grant NE/G013071/1. Many thanks to Jon Hill and Colin McClean from the Environment Department at the University of York, who provided advice and guidance on the methods used. We thank the editors (Hester Jiskoot and Neil Glasser) and two reviewers (Rob Bingham and one anonymous reviewer) for their helpful and insightful comments, which significantly improved this paper.

\section{REFERENCES}

Ballantyne CK and Small D (2018) The last Scottish ice sheet. Earth Env. Sci. Trans. R. Soc. Edin., 1-39 
Benn DI and Evans DJA (2010) Glacier \& glaciation, 2nd edn. Hodder Education, Abingdon

Bennett MR and Glasser NF (2009) Glacial geology, 2nd edn. WileyBlackwell, Chichester

Bingham RG and Siegert MJ (2007) Radar-derived bed roughness characterization of Institute and Möller ice streams, West Antarctica, and comparison with Siple Coast ice streams. Geophys. Res. Lett., 34, 1-5

Bingham RG and Siegert MJ (2009) Quantifying subglacial bed roughness in Antarctica: implications for ice-sheet dynamics and history. Quat. Sci. Rev., 28, 223-236

Bingham RG, Siegert MJ, Young DA and Blankenship DD (2007) Organized flow from the South Pole to the Filchner-Ronne ice shelf: an assessment of balance velocities in interior East Antarctica using radio echo sounding data. J. Geophys. Res., 112, 1-11

Bingham RG and 9 others (2015) Ice-flow structure and ice dynamic changes in the Weddell Sea sector of West Antarctica from radarimaged internal layering. J. Geophys. Res. Earth Surf., 120(4), 655-670

Bingham RG and 5 others (2017) Diverse landscapes beneath pine island glacier influence ice flow. Nat. Comms., 8(1618), 1-9

Bradwell T (2005) Bedrock megagrooves in Assynt, NW Scotland. Geomorphology, 65, 195-204

Bradwell T (2013) Identifying palaeo-ice-stream tributaries on hard beds: mapping glacial bedforms and erosion zones in NW Scotland. Geomorphology 201, 397-414

Bradwell T and Stoker MS (2015) Submarine sediment and landform record of a palaeo-ice stream within the British-Irish Ice Sheet. Boreas, 44, 255-276

Bradwell T and Stoker MS (2016) Glacial sediment and landform record offshore NW Scotland: a fjord - shelf - slope transect through a Late Quaternary mid-latitude ice-stream system. In Dowdeswell JA, Canals M, Jakobsson M, Todd BJ Dowdeswell EK and Hogan KA eds. Atlas of submarine glacial landforms: modern, quaternary and ancient. The Geological Society of London, London, 421-428

Bradwell T, Stoker M and Larter R (2007) Geomorphological signature and flow dynamics of The Minch palaeo-ice stream, northwest Scotland. J. Quat. Sci., 22, 609-617

Bradwell T and 11 others (2008a) The northern sector of the last British Ice Sheet: Maximum extent and demise. Earth-Science Rev., 88, 207-226

Bradwell T, Stoker M and Krabbendam M (2008b) Megagrooves and streamlined bedrock in NW Scotland: the role of ice streams in landscape evolution. Geomorphology, 97, 135-156

Bradwell T and 5 others (2016) Rate and style of ice stream retreat constrained by new surface-exposure ages: The Minch, NW Scotland. In: EGU. Vol. 18. p. 10447.

Callens D and 5 others (2014) Transition of flow regime along a marine-terminating outlet glacier in East Antarctica. Cryosphere, 8, 867-875

Chiverrell RC and Thomas GSP (2010) Extent and timing of the Last Glacial Maximum (LGM) in Britain and Ireland: a review. J. Quat. Sci., 25, 535-549

Clark CD (1993) Mega-scale glacial lineations and cross-cutting iceflow landforms. Earth Surf. Process. Landf., 18, 1-29

Clark CD, Hughes ALC, Greenwood SL, Jordan C and Sejrup HP (2012) Pattern and timing of retreat of the last British-Irish Ice Sheet. Quat. Sci. Rev., 44, 112-146

Clark CD and 13 others (2018) BRITICE glacial Map, version 2: a map and GIS database of glacial landforms of the last BritishIrish Ice Sheet. Boreas, 47(1), 11-27

DeConto RM and Pollard D (2016) Contribution of Antarctica to past and future sea-level rise. Nature, 531, 591-597

Finlayson AG, Golledge N, Bradwell T and Fabel D (2011) Evolution of a Lateglacial mountain icecap in Northern Scotland. Boreas, 40(3), 536-544

Fretwell P and 59 others (2013) Bedmap2: improved ice bed, surface and thickness datasets for Antarctica. Cryosphere, 7, 375-393
Fyfe JA, Long D and Evans D (1993) The geology of the MalinHebrides sea area. UK Offshore Reg. Rep.,

Gudlaugsson E, Humbert A, Winsborrow M and Andreassen K (2013) Subglacial roughness of the former Barents Sea ice sheet. J. Geophys. Res. Earth Surf., 118, 2546-2556

Hubbard B and Hubbard A (1998) Bedrock surface roughness and the distribution of subglacially precipitated carbonate deposits: implications for the formation at Glacier de Tsanfleuron, Switzerland. Earth Surf. Process. Landforms, 23(3), 261-270

Hubbard B, Siegert MJ and McCarroll D (2000) Spectral roughness of glaciated bedrock geomorphic surfaces: implications for glacier sliding. J. Geophys. Res., 105, 21295

Hubbard A and 7 others (2009) Dynamic cycles, ice streams and their impact on the extent, chronology and deglaciation of the British-Irish ice sheet. Quat. Sci. Rev., 28(7-8), 758-776

Intermap Technologies (2009) NEXTMap British Orthorectified Radar Image (ORI) Data by Intermap. NERC Earth Obs. Data Cent. [Internet]. Available from: http://catalogue.ceda.ac.uk/ uuid/90de599e45a84d36a16cf01904048705

Jordan TM and 6 others (2017) Self-affine subglacial roughness: consequences for radar scattering and basal thaw discrimination in northern Greenland. Cryosphere, 11, 1247-1264

Joughin I and Bamber JL (2005) Thickening of the ice stream catchments feeding the Filchner-Ronne Ice Shelf, Antarctica. Geophys. Res. Lett., 32(17), 1-4

Joughin I, Smith BE and Medley B (2014) Marine ice sheet collapse potentially under way for the Thwaites Glacier Basin, West Antarctica. Science, 344, 735-738

Kamb B (1970) Sliding motion of glaciers: theory and observation. Rev. Geophys., 8, 673-728

King EC, Hindmarsh RCA and Stokes CR (2009) Formation of megascale glacial lineations observed beneath a West Antarctic ice stream. Nat. Geosci., 2, 585-588

King EC, Pritchard HD and Smith AM (2016) Subglacial landforms beneath Rutford Ice Stream, Antarctica: detailed bed topography from ice-penetrating radar. Earth Syst. Sci. Data, 8, 151-158

Krabbendam M (2016) Basal sliding on a rough hard bed; pressure melting and creep mechanisms in temperate basal ice. Cryosphere, 10, 1915-1932

Krabbendam M and Bradwell T (2010) The geology and landscape of the Northwest Highlands: an introduction. In Lukas S and Bradwell T eds. The quaternary of western Sutherland and adjacent areas: field guide. Quaternary Research Association, London, 3-12

Krabbendam M and Bradwell T (2011) Lateral plucking as a mechanism for elongate erosional glacial bedforms: explaining megagrooves in Britain and Canada. Earth Surf. Process. Landforms, 36, 1335-1349

Krabbendam M and Bradwell T (2014) Quaternary evolution of glaciated gneiss terrains: pre-glacial weathering vs. Glacial erosion. Quat. Sci. Rev., 95, 20-42

Krabbendam M, Eyles N, Putkinen N, Bradwell $T$ and ArbelaezMoreno L (2016) Streamlined hard beds formed by palaeo-ice streams: a review. Sediment. Geol., 338, 24-50

Kuchar J and 6 others (2012) Evaluation of a numerical model of the British-Irish ice sheet using relative sea-level data: implications for the interpretation of trimline observations. J. Quat. Sci., 27(6), 597-605

Layberry RL and Bamber JL (2001) Between dynamics and basal topography. J. Geophys. Res., 106, 33781-33788

Leuschen C and 6 others (2014) UAS-based radar sounding of the polar ice sheets. IEEE Geosci. Remote Sens., 2(1), 8-17

$\mathrm{Li}$ X and 7 others (2010) Characterization of subglacial landscapes by a two-parameter roughness index. J. Glaciol., 56, 831-836

Lindbäck K and Pettersson R (2015) Spectral roughness and glacial erosion of a land-terminating section of the Greenland Ice Sheet. Geomorphology, 238, 149-159

MacGregor JA and 11 others (2016) A synthesis of the basal thermal state of the Greenland ice sheet. J. Geophys. Res. Earth Surf., 121, $1328-1350$ 
Margold M, Stokes CR and Clark CD (2015) Ice streams in the Laurentide Ice Sheet: Identification, characteristics and comparison to modern ice sheets. Earth-Science Rev., 143, 117-146

Mouginot J, Scheuchl B and Rignot E (2012) Mapping of Ice motion in Antartica using synthetic-aperture radar data. Remote Sens., 4, 2753-2767

$\mathrm{Ng} \mathrm{F}$ and Conway H (2004) Fast-flow signature in the stagnated Kamb Ice Stream, West Antarctica. Geology, 32(6), 481-484

Nye JF (1970) Glacier sliding without cavitation in a linear viscous approximation. Proc. R. Soc. Lond. A., 315, 381-403

Ordnance Survey (2017) Ordnance Survey Meridian 2. Southampton: Ordnance Survey

Perkins AJ and Brennand TA (2014) Refining the pattern and style of Cordilleran Ice Sheet retreat: Palaeogeography, evolution and implications of lateglacial ice-dammed lake systems on the southern Fraser Plateau, British Columbia, Canada. Boreas, 44, 319-342

Praeg D 8 and others (2015) Ice sheet extension to the Celtic Sea shelf edge at the Last Glacial Maximum. Quat. Sci. Rev., 111, 107-112

Prescott PW (2013) Quantifying subglacial roughness and its link to glacial geomorphology and ice speed. (Doctoral thesis, Durham University)

Putkinen N and 13 others (2017) High-resolution LiDAR mapping of glacial landforms and ice stream lobes in Finland. Bull. Geol. Soc. Finland., 29, 64-81

Rignot E, Mouginot J and Scheuchl B (2011) Ice flow of the Antarctic Ice Sheet. Science, 333, 1427-1430

Rinterknecht $V$ and 7 others (2014) Unstable ice stream in Greenland during the Younger Dryas cold event. Geology, 42, 759-762

Rippin DM (2013) Bed roughness beneath the Greenland ice sheet. J. Glaciol., 59, 724-732

Rippin DM, Bamber JL, Siegert MJ, Vaughan DG and Corr HFJ (2006) Basal conditions beneath enhanced-flow tributaries of Slessor Glacier, East Antarctica. J. Glaciol., 52, 481-490

Rippin DM, Vaughan DG and Corr HFJ (2011) The basal roughness of Pine Island Glacier, West Antarctica. J. Glaciol., 57, 67-76

Rippin DM and 9 others (2014) Basal roughness of Institute and Möller Ice Streams, West Antarctica: process determination and landscape interpretation. Geomorphology, 214, 139-147

Roberts DH, Evans DJA, Lodwick J and Cox NJ (2013) The subglacial and ice-marginal signature of the North Sea Lobe of the British-
Irish Ice Sheet during the Last Glacial Maximum at Upgang, North Yorkshire, UK. Proc. Geol. Assoc., 124, 503-519

Ross $\mathrm{N}$ and 9 others (2012) Steep reverse bed slope at the grounding line of the Weddell Sea sector in West Antarctica. Nat. Geosci. $5,1-4$

Ross N and 8 others (2014) The Ellsworth Subglacial Highlands: Inception and retreat of the West Antarctic ice sheet. Bull. Geol. Soc. Am., 126, 3-15.

Salcher BC, Hinsch R and Wagreich M (2010) High-resolution mapping of glacial landforms in the North Alpine Foreland, Austria. Geomorphology, 122(3-4), 283-293

Scambos T, Bohlander J, Raup B and Haran T (2004) Glaciological characteristics of Institute Ice Stream using remote sensing. Antarct. Sci., 16, 205-213

Schoof C (2002) Basal perturbations under ice streams: form drag and surface expression. J. Glaciol., 48(162), 407-416

Schroeder DM, Blankenship DD, Young DA, Witus AE and Anderson JB (2014) Airborne radar sounding evidence for deformable sediments and outcropping bedrock beneath Thwaites Glacier, West Antarctica. Geophys. Res. Lett., 41, 7200-7208

Shepard MK and 5 others (2001) A planetary and remote sensing perspective. J. Geophys. Res., 106, 32,777-32,795

Siegert MJ, Taylor J, Payne AJ and Hubbard B (2004) Macro-scale bed roughness of the Siple Coast ice streams in west Antartica. Earth Surf. Process. Landforms, 29, 1591-1596

Siegert MJ, Taylor J and Payne AJ (2005) Spectral roughness of subglacial topography and implications for former ice-sheet dynamics in East Antarctica. Glob. Planet. Change, 45, 249-263

Siegert MJ and 7 others (2016) Subglacial controls on the flow of Institute Ice Stream, West Antarctica. Ann. Glaciol., 57, 19-24.

Smith MW (2014) Roughness in the Earth Sciences. Earth-Science Rev., 136, 202-225

Spagnolo M and 12 others (2017) The periodic topography of ice stream beds: insights from the Fourier spectra of mega-scale glacial lineations. J. Geophys. Res. Earth Surf., 122, 1355-1373.

Taylor J, Siegert MJ, Payne AJ and Hubbard B (2004) Regional-scale bed roughness beneath ice masses: measurement and analysis. Comput. Geosci., 30, 899-908

Vaughan DG and 9 others (2006) New boundary conditions for the West Antarctic ice sheet: subglacial topography beneath Pine Island Glacier. Geophys. Res. Lett., 33(9), 1-4.

Weertman J (1957) On the sliding of glaciers. J. Glaciol., 3, 33-38

Winsborrow MCM, Clark CD and Stokes CR (2010) What controls the location of ice streams? Earth-Science Rev., 103, 45-59 